\title{
Military Progress in the Global World: new Tendencies and Problems
}

\author{
Sergey V. Maximov* \\ Siberian Federal University \\ 79 Svobodny, Krasnoyarsk, 660041, Russia
}

Received 29.11.2014, received in revised form 20.12.2014, accepted 29.01.2015

The present article analyses peculiarities of military progress manifestation in the global world. The author relies on the thesis that military progress acts as a part of social progress. He demonstrates that the nature of military progress is contradictory, as it may manifest itself as more than just technical progress. The article draws attention to the fact that military progress may be also described with such concepts as valour, patriotism, courage. The author proves that in different societies military progress depends on their historical traditions.

Military progress is a permanently evolving system which gains significance with one set of parameters in one case, but requires a radically different one in another. This fact gives us opportunity to study different structures of military progress and dynamics of the features that come to the fore, being taken for military progress during a given historical period. Moreover, military progress is expected to present an aggressive component of the social progress, as it is military progress that maximally characterizes the society's capacity to confront any external threat.

Understanding of the military progress concept requires adequate assessment of its deployment along with the indicators of economic, political, spiritual, and social spheres of social life. The process of military progress must make the enemy constantly find itself in a catching-up, unpredictable position. Keeping the enemy this way makes it feel weak. In such a case, military progress can be said to satisfy the social expectations. For instance, military exhibitions are intended to demonstrate the types of armour the enemy lacks, making them feel weak in the spiritual, social, political, and economic aspects of their military progress.

In the author's opinion, dialectic approach to military progress suggests several principal trends. If military progress acts as a component of an aggressive process in social life, it requires a wellplanned strategy and tactics. Strategy suggests a situation, in which the enemy is in permanently tense condition for a long period of time: they are forced to think for us, assuming where we might go and what our ideas might be. We need to bring the enemy to the situation of entropy, making all its actions as costly and socially uncomfortable as possible. To fulfil such a task, we need to study the enemy continuously and profoundly. It is important to think of what our actions should be to cause the enemy make some ill-advised, and at the same time costly steps.

Military progress is closely associated with potential war that takes new features in the today's global world. Global connections are made by means of the rapidly developing global communication network, military and technical factors, environmental problems, migration processes, expanding international contacts of different kinds, especially cultural ones, international relations system and the need for regulation of the processes going on in the global community.

(C) Siberian Federal University. All rights reserved

* Corresponding author E-mail address: maxserge@mail.ru 
As the author demonstrates, in the modern global world military progress is determined by the anthropocentrism and dualism principles. These principles characterize the metaphysical method, which suggests studying phenomena in an isolated way, and confrontation of external opposite forces as the main drivers of development.

Complexity, dynamics, arrhythmy, sophistication and multiactorness of the modern war lets us speak of a new type of war called multidimensional non-linear war. It is important to have adequate understanding in what parts and aspects of the modern multidimensional non-linear war the use of cyber-weapon may bring the maximal result.

Contrasting Russian way of development to the European one, Russian philosophers agree with their Western colleagues in outlining such features of progress as loss of genuine human personality, domination of the civilizational (technical, artificial) over the cultural (spiritual, existential). The difference is in the understanding of the source of spiritual culture. In European concept it is the autonomous personality guided by its individual system of values and cultural regulations. In Russian philosophy this personality is the reflection of the divine, the revelation of which is the ascendance from the individuality of universal harmony.

Keywords: military progress, global world, regional conflicts, military confrontation, social progress, military threat, cyber weapon.

Research area: philosophy.

The urgency of the problems caused by the peculiarities of military progress concept is determined by the principal transformations that characterize the current global world order. The major change happening these days is the competition between civilizations, the cultural and historical communities united by more than just some tight economic bond, but also by some deeper factors. To develop the correct military progress vector, it should be considered that the war between the national mafias is not exterminatory; it is a fight for the spheres of influence over the majority. As it has been mentioned in various researches, the pattern of evolution must contribute to finding the ways and methods of administering the social evolution [26].

Organization of the military progress based on logical principles reflects its dynamics on the macro level, adjusted for institutional functioning within the society. However, this method of organization reveals its insufficiency in carrying out a scientific search and in expressing the dynamics of knowledge used to justify its sustainability. Theattemptsto systematizemilitary progress were inclined either to descriptive history (maximum amount of established factors, interpreted and conceptualized on the basis of elementary theoretical constructions adopted from non-historical disciplines or common sense), or to theorized (logocentric) history (maximum of logical diagrams transferred from other social sciences and minimum amount of facts).

Military progress is a permanently evolving system which gains significance with one set of parameters in one case, but requires a radically different one in another. This fact gives us opportunity to study different structures of military progress and dynamics of the features that come to the fore, being taken for military progress during a given historical period. Moreover, military progress is expected to present an aggressive component of the social progress, as it is military progress that maximally characterizes the society's capacity to confront any external threat.

Understanding of the military progress concept requires adequate assessment of its deployment along with the indicators of economic, political, spiritual, and social spheres 
of social life. The process of military progress must make the enemy constantly find itself in a catching-up, unpredictable position. Keeping the enemy this way makes it feel weak. In such a case, military progress can be said to satisfy the social expectations. For instance, military exhibitions are intended to demonstrate the types of armour the enemy lacks, making them feel weak in the spiritual, social, political, and economic aspects of their military progress.

Military progress is closely associated with potential war that takes new features in the today's global world. In the modern global world military progress is determined by the anthropocentrism and dualism principles. These principles characterize the metaphysical method, which suggests studying phenomena in an isolated way, and confrontation of external opposite forces as the main drivers of development.

Every species of social progress corresponds to a genus of social progress; for instance, individualistic society progress corresponds to the slave-holding, feudal, capitalistic and other genera of social progress. As for progress of a collectivist society, it is evident that its genera are associated with the need to overcome the social chaos, social entropy, so to say, "Gardariki type" of progress, which stands for building a "kingdom of cities" as a form of fixing the population on the problematic (for geographic, geopolitical and other reasons) territory of the country [36].

With increasing frequency scholars and military specialists emphasize that "the new generation wars will be pursued under the laws and regulations of the party which is better prepared for deployment of the latest achievements in the military, economic and technological spheres" [34]. For instance, the Kosovo crisis became the starting point for the emergence of so-called "new humanism" described as follows. There are new concepts of the world order coming up, imbued with the inspiring experience of the human relations and the global community. These new concepts are intended to substitute the institutions of the decaying world order demonstrating their "morbid weakness", condemned to being preferred to the new ideas with their "innovative but plausible" deviation from the previous norms. We may agree with the opinion that "...such events act as a sort of fair strength test of the "new humanism" in the sphere it has selected; they also demonstrate proprietary inner value and significance at least for the elementary moral regulations" [33].

Today there is a sharper contrast between the state terror carried out with the approval and impatient support of the civilized states or mostly their governments, and the state terror perceived as villainy, worthwhile a severe punishment at least because it contradicts their requirements. "It is surprising that during the whole criminal and bloody history of this "new Atlantis" the myth of the "shining city in the ocean blue" has not been busted. Neither slaughter of Indians, nor wars against Canada and Mexico, nor gangsterism and reprisal against trade unions, nor atomic bombs dropped on Hiroshima and Nagasaki, nor even Vietnam... Nothing shattered the rock-solid admass dream of the overseas land of freedom and prosperity. But the myth surviving through the two centuries of obvious demonstration of the opposite was suddenly busted in an instant, within several years... At the end of the decade, only people with hopeless diagnosis may still associate the geopolitical brand of the USA with any positive ideas" [7].

The cyber-space, which acts as a theatre of war along with land, sea, air and space, gains more and more significance in the modern world. In this aspect cyber-war is one of the major revolutionary vectors in the art of war, deploying in front of our eyes. Cyber war is a special type of war with its distinctive features, peculiarities and weapon. For example, during the war in Syria 
the government forces had to confront the combat units of terrorists, contractors and extremists, dispersed around the territory of Syria. And though there had been no summarized materials proving the facts of cyber-attacks and cracking the secured communication system codes during the Syrian war, the Syrian, independent Western mass media and the electronic sources traditionally associated with Israeli intelligence provided a lot of evidence that the antigovernment forces had been actively using cyberweapon to deactivate electronic communication systems of the Syrian army, to crack the codes and distort the information transferred via secret communication channels.

The military progress study is seriously challenged by the fact that the historical progress concept is categorically equalled to the system of development and strengthening of Western values and associated with the "end of history" by a significant fraction of philosophers. However, the generally utopic "end of history" "pan-human state" concept of Fukuyama, though based on the values of market and liberal democracy, is evident not to be standing up to criticism in the face of the escalating national, cultural, and religious self-identification of nations against the global civilization crisis of the $21^{\text {st }}$ century [22]. Even the avid globalization ideologists are raising alarm: "today the European nations are being convinced that justice requires them to open borders and share shelter with the descendants of the people oppressed by their ancestors, no matter how many of them there are, to "compensate" their past sins. Can Europeans upturn the uncompromising demands of the cultural Marxists? What they are demanded for is neither more nor less than demographic, national and cultural suicide, for the good of humankind, of course" [3].

Liberalization of the world, which makes international travelling easier for the intellectual elite, and globalization, bringing free travel of technology and capital, lead to concentrating the major resources of the information era in the most economically favourable zones [13]. For instance, the modern era transhumanism is distinctive for its specificity. "As the cold war was fading, there were some problems of the larger scale that rose to the fore and got in the centre of the politicians' attention due to the wars caused by the breakup of Yugoslavia. Among their major roles there is the demand of the states or alliances for the right to interfere in those events on humanitarian basis, due to which they would be able to significantly expand the diapason of legal resort to force. Military specialists remark new important tendencies of transhumanism: “...in the Desert Storm operation against Iraqi army the Multinational forces were aiming at achieving the information advantage over the enemy by uniting the multifold military objects into an information network. In the West, this war is often defined as the fight of "the sighted against the blind" [30].

Completing the Russian cyber-troops formation and getting them fully operational are the key components of the systematic "measures, intended to forestall or reduce the threat of destructive action on the part of a state aggressor (coalition of states)" foreseen by the National security strategy of the Russian Federation to 2020 [15].

We may agree with the thinkers who are convinced that the time to write the real story of Russia has come [19]. Only multipolar world can stop American globalism, and it is the only world in which Russia has a chance to maintain its sovereignty and identity. Preservation and development of its national culture will boost the process. We may also agree with G. Meyer: "Future emerges from the memorable past. If there is no memory of the past, the future will never come true, and it will all turn to chaos and come crashing down the eternal, prehistoric, featureless and indifferent abyss. Human memory 
is in creative motion. And the most precious of its features is the unquenchable desire to idealize the past. Unlike the idylls, expected in the future and imagined in the present, permanently pointless and dead, idealization of the past is the collateral for our own immortality. Idealizing the past the memory performs the act of selection, purifying all the genuinely heroic deeds of the temporary and the obsolete... Idealizing the past, we enter into a loving union with it, conferring it forever" [17].

General and specific problems of social development are tightly connected to the modern global problems. The major one is the problem of preventing a new war, of terminating the arms race, wasting enormous material and labour resources of the humankind. According to the $\mathrm{UN}$, cutting the general military expenditures by 20 per cent would solve the most acute economic issues of the world, significantly narrowing the economic gap between the developed and developing countries.

In the late $20^{\text {th }}$ century, the humankind was challenged with the problem of survival when the scientific and technical progress brings more and more opportunities for developing brand new military technologies and weapons of mass destruction. In the modern geopolitical situation there is a tight interdependence between the external and internal political threats. Ignore of the circumstances by our country's government in the 90-s caused some truly catastrophic consequences for the economy, military and scientific potential of Russia, the wealth of its people, considerably weakening its hand in the international arena.

It seems like no one noticed that the USA did not actually terminate the Cold War against Russia after 1991, keeping it under the motto of "new inhibition", i.e. encouraging and striving for the maximum weakening, plunder of the $\mathrm{RF}$, destruction of its sovereignty, bringing it to universal poverty as the basic condition of undermining its international and domestic positions. The White House achieved the target with the support of the powerful pro-American lobby and oligarch mafia structures that emerged in Russia under the auspices of the States. As far back as before the presidential elections, Vladimir Putin remarked that by the year 2000 "Russia had significantly given grand in the international arena. While the forces that kept on living the Cold War stereotypes, despite their "honey words", still regarded Russia as a political enemy, showing all possible support to any attempts to conserve our country in the state it currently is" [6].

Contrasting Russian path of development against the European one, Russian thinkers agree with their Western colleagues in outlining such features of progress as loss of genuine human personality, domination of the civilizational (technical, artificial) over the cultural (spiritual, existential). The difference is in the understanding of the source of spiritual culture. According to the European concept, it is the autonomous personality guided by its individual system of values and cultural regulations. In Russian philosophy this personality is the reflection of the divine, the revelation of which is the ascendance from the individuality of universal harmony.

The scholars researching the nature and essence of wars often rely on the comparative analysis of the World Wars I and II. For instance, in his book "The Causes and Prevention of War" published in New York, 1987, Seyom Brown remarked that during the pre-war decade the major alliances inspired the confrontational diplomacy that caused the war and determined its scale. However, during the decade before the World War II, the absence of any weighty opposing alliances had inspired Adolf Hitler, Benito Mussolini and the Japanese military forces to start the aggression that lead, in the end, to the 
new global war. The previous system of alliances had been consciously annihilated by the World War I "winners", as claimed in the theses of the US President Woodrow Wilson widely supported on the both sides of the Atlantic that the system of power and alliance balances is the main cause of the war" [2]. According to N. Rozov, researcher of the war and peace problem, “...a war cannot be explained with any personal misconception, imperfection of the social system or the ill will of some groups or persons. The war requires more than purely scientific, but generally philosophic and, first of all, ontological understanding of its essential base and original sources" [23]. In his turn, R. Glosson believes that war is a "widescale violent conflict between the organized government groups or the groups striving to establish their governments" [5].

The need for military progress is also connected to the fact, that, paradoxically, under the modern conditions it is intended to prevent the ultimate form of international confrontation, which is the war. In its turn, it escalates the information war based on "demonization" of the enemy as an essential condition for justification of the arms race. "One of the main reasons for violence escalation is the unusual democratization of war. Total conflicts turn into "the wars of people", since the civilian population and civil life become the appropriate, or even the main targets in military strategy development, and also because in democratic war, just like in democratic politics, the enemies are sure to be demonizing each other, exposing each other to odium or, at least, despise" [33].

Nevertheless, there are some clear-headed politicians who realize that the main task of military progress is to prevent the nuclear war that has neither winners nor losers. That is why military progress includes thorough analysis of the art of war of the previous eras. As R. Collins remarked, if we want to understand the conditions for the existence of social order, we need to compare them to the conditions that cause its destruction [10]. In this connection the analysis of the causes of war and pre-war events, i.e. of the facts that provoked the military conflict in this or that way, gains the principal significance.

Military history proves that there are no military unions carrying no military purpose. Today no one recalls The Charter of Paris for a New Europe signed in November (November 1990). Gorbachev fulfilled his obligations, but the West did not. With a stroke of the pen Gorbachev eliminated two-thirds of our military potential, opening opportunities for closer cooperation between the East and the West. However, a lot was done in the way the West saw it. Any historian can confirm that in the process of reunification of Germany the secretary of state James Baker promised to expand NATO eastwards. In our turn, we enjoy the situation where there are NATO troops in eight of the fifteen former Soviet republics, and a NATO base located one hour drive away from Saint Petersburg.

That is why the problem of military threat, tightly associated with military progress, is getting more and more urgent. For instance, the recently formulated Military Doctrine defines the term of "military hazard" regarded as "...a state of international or domestic relations characterized with the totality of factors which, under certain conditions, may lead to the emergence of a military threat". This is why there is such strong demand for military progress and, particularly, "l) military planning, determination of the order and methods for actualization of the development purposes and tasks of the military organization, construction and development of the Armed Forces and other corps, along with means for their deployment and comprehensive maintenance" [4].

Military progress cannot be adequately perceived with no regard to the fact that the 
territorial expansion of the State of Russia was caused by combination and proportion of certain circumstances, not by a deliberate policy of the ruling parties. True military progress assumes a certain historical basis; that is why perversion of history is one of the most common acts in the information war.

In his book [28], Thomas Taylor praises the wisdom of Eisenhower who granted the honour to assault Hitler's lair to Zhukov, knowing that the losses would be enormous. However, several pages after he reproaches Stalin for having betrayed Armia Krajowa, refusing to assault Warsaw. However, it is known that the "Krajowans" started a rebellion over the Soviet leaders' head and did not count us for allies at all. The Warsaw assault was a risk of great loss. It is telling that for the author the Soviet and American victims are measured with two different scales.

Despite stand-alone problems and conflicts, there used to be the atmosphere of national and religious tolerance in the country. It was formed not only by the flexible policy of the government, but also as a consequence of Russian mentality that accepted such policy [24]. Nevertheless, American military historian Michael Lanning included Napoleon and Hitler in his book "The Military 100: A Ranking of the Most Influential Military Leaders of All Time" but did not mention Kutuzov or Stalin. Moreover, he put Suvorov on the $50^{\text {th }}$ place, but pushed Zhukov as back as the $70^{\text {th }}[8]$.

However, Russia at the time did not have any politicians of the level of P.I. Milyukov, a great historian and a State Duma Deputy. In the early $20^{\text {th }}$ century he was obliged to admit special responsibility of the politicians in the war prevention issue. "Of course, we must admit that we, the Progressive Block of the State Duma, are the ones to bear responsibility for what has happened. You know that the firm decision to take advantage of the war to perform the revolution was made soon after the beginning of the war; you also know that we could wait no more, being aware that by the end of April or the beginning of May our army would have taken the offensive, the result of which would eradicate any hints of discontent, cause a boom of patriotism and cheer in the country. The history will curse the proletariat, and so it will curse us, the ones to have caused this storm" [14].

A distinctive feature of our time is virtualization of the political and informational space. For example, the "peace maker", the Nobel Peace Prize winner Barack Obama did not just finish the war in Afghanistan, but also increased the contingent of troops by 30 thousand people, started a war in Libya etc. "World development at the present stage is characterized by a weakening of ideological confrontation, a lowering of the level of economic, political, and military influence of certain states (groups of states) and alliances and an increase in the influence of other states with ambitions for all-embracing domination, multipolarity, and the globalization of diverse processes. Many regional conflicts remain unresolved. There is a continuing tendency towards a strong-arm resolution of these conflicts, including those in the regions bordering on the Russian Federation. The existing international security architecture (system), including its legal international mechanisms, does not ensure any universal security for all states" [4]. As V.V. Putin remarked, "We need mechanisms of response to more than the existing hazards. We need to learn how to "see over the horizon", assess the hazards 30-50 years ahead. Basically, we need to create a dramatically new, "smart" system of military analysis and strategic planning, preparation of new "recipes" and ways of actualizing them within our power-wielding agencies" [21].

The ultimate purpose of globalization is hidden in the Western desire to impose their civilization order as the only right and 
genuine one on all the non-western cultural and historical communities. Among the tools of such globalization there are: decay of the national identity of people and nations; undermining of sovereignty; primate of international law and establishment of total control over the sovereign power systems; elimination of protectionist barriers, customs borders and other boundaries in the universal financial and economic space; informational transparency" [40]. At the present time, peace is more than a preferred way of human life or a favourable prerequisite for social progress.

The problem of extermination of wars, complete exclusion of war from social life, or the problem of strong universal peace as an essential condition for the very existence and progressive development of the humankind in the nearest and distant historical prospective is now faced as not just a theoretical, but as a certain practical problem that requires a solution right now, for the present generation.

Survival and prosperity of societies and states depends, first of all, on the background of the elite, its capacity for proactive response to the new world's challenges. Ultimately, on the "quality of human capital" [25].

The idea on providing security through development was adequately formulated in the recently published sustainable development concept. The primary important factor is the inclusion of the sustainable development term in the "texture" of Strategy 2020, the regulatory legal act of the President of the Russian Federation, where it is mentioned in the very first article [27].

Despite its peculiarities, being an organic part of the universal civilization, Russia is expected to accumulate the positive experience of democratic development. The state of Russia will not only be held responsible for it; it is expected to transform in accordance with the requirements and principles of the new civilizational order, making its contribution into development of the world as a whole" [20].

The guarantee for the prospective of building a new community on the collectivist principle is the fact that, no matter in what terms, Russian philosophy has been restlessly seeking for ideal grounds for the human existence in the world. That is where the eternal utopianism of Russian consciousness and self-identity, impressed in the philosophic tractates, originates from. It may be evaluated as an advantage or a disadvantage, but it is an obvious peculiarity of our philosophic and pedagogical anthropology [35]. That is what the sad irony of history is about: Russian communism, theoretically relied on economic materialism, i.e. on the belief in absolute dependence of the political development on the economically shaped power of the country, is condemned to living on the hopeless position where its political conditions contradict the economic ones. The entire contradiction is invincible for communism itself, causing its ultimate collapse sooner or later [29].

If anti-Christian and non-Christian (PostModernist) globalization continues with the same momentum and in the same direction, then in the future, no matter how hard it is to admit, the Orthodox-Russian civilization may have to transform within the hidden ("catacombal") Church and all associated sociocultural relations [9].

It is necessary to account for the new tendencies typical for military progress and outlined by many thinkers. For instance, at the futurology congress that was recently held in Moscow, the idea of the dead-end prospective of "the stake on Western Europe" and the need for Russia to "turn its face to China" was explicitly expressed. It should be noted that it was not expressed by a random person; the initiator was the patriarch of Western futurology Alvin Toffler [16]. 
The way out of the total crisis of the world's civilization is the spiritual reformation, a gradual transition to a different global system of values ("ideational", after Pitirim Sorokin). The world community is challenged with a new task to build a spiritual vertical in the place of the consumer horizontal; express new future in the language of its proprietary spiritual tradition, offer the world, seeking for a global consciousness revolution, a post-consumerist, post-technological, posteconomic alternative" [31]. However, many Russian democrats still do not want to admit being led a merry dance. It started back in the era of Gorbachev who gave East Germany away with the condition that it would not enter NATO. Today these memories make us think of the naivety of Russian politicians who believed the West on its bare word [1].

Russia is a part of the humankind, and the humankind has entered the systematic civilizational crisis stage that is coming to a bifurcation with an unpredictable result. Russia is about to solve a problem of the planetary scale: to find a way of preventing the possible end of the humankind. "Russia can, and it shall, accept the burden of the humankind "calling" for reunification in order to get over the crisis and prevent the end of civilization; it must raise the banner of renovation of the humankind and never let it go. This idea can be accepted by Russian people, it can unite the nation if the true facts of the matter and the thread of the universal collapse are revealed to it. People will agree to work and to stand everything for the sake of achieving the goal. Such goal will contribute to the transformation of the people's understanding of their belonging to the society. It will determine the basic priorities in the acts of government; it will assist in the relationships between Russia and other countries. It will increase the probability of finding the coevolutionary path of development for the human society, which is the only possible path to the future" [39].

Understanding of the mechanism informational and tectological spirituality is an important and essential condition for understanding of the social structure that determines the specificity of practical transformation and optimization of the social relations. It becomes urgent and more necessary than just so-called "sustainable development of the society", global or anti-global development of the society; it will mean the development of a natural, cosmos-adequate perfection of the social medium as a harmonized medium for human existence [11].

There is no society and no state that would reach long-term stability and security without a pattern of sustainable development. The security problem turns out to be the primary and the fundamental one for switching the type of the further development of a country in particular and the civilization as a whole. However, the level and the principles of security depend on the development type of the material system (or in this case, on the socioeconomic development) the author pays special attention to. Implementation of the civilization plan requires a sciencebased forecast and a system of socioeconomic development planning that relies on it [18].

Therefore, the failing attempt of enforced construction of the monopole world assumes consensus in understanding security despite various interpretations of military progress in the modern globalizing world. However, the possibility of the global war between the nuclear states is not that high, as it would mean the end of the civilization. In the tactical sense, military progress is not a simple sum the military strategy is developed from, but a dialectic unity, where immediate quantitative results and stand-alone contradictions form a fundament for victories and strategic development of a given state. 


\section{References}

1. Afanasyev V.V. Novyy mirovoy poriadok i mirotvorcheskaia rol' Zapada [New World Order And Peace-Making Role Of The West] // Rossiia i Evropa: natsii v epokhu globalizatsii / edited by V.V. Afanasyev. Moscow, M.V. Lomonosov Moscow State University, 2008. P. 147-148.

2. Brown S. Prichiny voyny: strukturnye faktory [The Causes And Prevention Of War] // Voyna i geopolitika. Vol. 3. Vremia mira. Novosibirsk, 2003. P.64.

3. Buchanan P.J. Smert' Zapada [The Death Of The West] Moscow: OOO AST Publishing House; Saint Petersburg: Terra Fantastica, 2003. P. 327.

4. Military Doctrine of the Russian Federation. Approved by the Decree of the President of the Russian Federation on February 5, 2012.

5. Glosson R. Priroda voyny [The Nature Of War] // Voyna i geopolitika. Vol 3. Vremia mira. Novosibirsk, 2003. P. 189-218.

6. Dashichev V. Global'nye otvety na global'nye vyzovy [Global Responses To Global Challenges] // Literaturnaya gazeta. March 14-20, 2007.

7. Jemal' G. DNK vremeni [The DNA Of Time] // Odnako. 2011. September 5, P. 20-21.

8. Zhukova L. Mesto v istorii [A Place In History] / L. Zhukova // Literaturnaya gazeta. 2011. June 29-July 5.

9. Kazin Srednen'kie evropeytsy [Mediocre Europeans] // Literaturnaya gazeta. 2011. January 25-31. P.3

10. Collins R. Konflikt $s$ primeneniem nasiliia $i$ sotsial'naia organizatsiia: nekotorye teoreticheskie sledstviia iz sotsiologii voyny [Violent Conflict And Social Organization. Some Theoretical Implications Of The Sociology Of War] / R. Collins // Voyna i geopolitika. Vol. 3. Vremia mira. Novosibirsk, 2003. P. 35.

11. Kolmakov V.Iu. Dukhovno-informatsionnaia tektologiia kul'tury [Spritual And Informational Tectology Of Culture] // Teoriia i istoriia. 2004, № 3. P. 138.

12. Kosolapov R.I. Istina iz Rossii [The Truth From Russia]. Tver', 2004. P. 29.

13. Kudashov V.I. Russkiy mir i natsional'naia ideiia [Russian World And National Idea] // Teoriia i istoriia. 2003, № 2. P. 49-50.

14. Lavrov V. Bran'i uzhas [Curse And Horror] / V. Lavrov // Literaturnaia gazeta. 2001 September 8-14.

15. Larina E., Ovchinskiy V. Piatoe izmerenie [The Fifth Dimension] // Zavtra. December 2, 2013.

16. Mezhuev B.V. Poniatie "natsional'nyy interes" v rossiyskoy obschestvenno-politicheskoy mysli [The Concept Of "National Interest" In Russian Sociopolitical Philosophy] // Polis. 1997, № 1. P. 5-31.

17. Meyer, G. Porugannoe chudo [The Profaned Wonder] // Voprosy filosofii, 2006, № 10. P. 105 .

18. Pozdniakov A.V. Ustoychivoe razvitie, singuliarnye tendentsii $i$ rol' nauki $v$ razvitii tsivilizatsii [Sustainable Development, Singular Tendencies And The Role Of Science In Civilization Development]. Optical Monitoring Institute of Siberian Department of Russian Academy of Science, Tomsk, 2002. 
19. Poliakov V. Poliubili sgoriacha Trotskogo i Il'icha. Konets "ogonkovskogo" kratkogo kursa istorii Rossii? [Hot Head Love For Trotsky And Lenin. The End Of The "Ogonyok" Short Course Of Russian History?] // Literaturnaia gazeta, 2007. № 4. April, 10.

20. State of the Nation Address on National Security. Moscow, 1996. P. 32.

21. Putin V.V. Byt'sil'nymi: garantii natsional'noy bezopasnosti dlia Rossii [Be Strong: Guarantee For Russia's National Security] / V.V. Putin // Rossiyskaia gazeta, 2012. February 20.

22. Pfanenshtil' I.A., Pfanenshtil' L.N. Rossiia i globalizatsiia: problemy i perspektivy [Russia And Globalization: Problems And Prospectives] // Kul'tura informatsionnogo obschestva. Krasnoyarsk, 2003. P.67.

23. Rozov N. Voyna vsegda riadom: suschnost' i proiskhozhdenie massovogo organizovannogo nasiliia [War Is Always There: Essence And Origin Of Massive Organized Violence] // Voyna i geopolitika. Vol. 4. Vremia mira. Novosibirsk, 2003. P. 76.

24. Rossiyskaia imperiia. Ot istokov do nachala XIX veka: ocherki sotsial'no-politicheskoy i ekonomicheskoy istorii [Russian Empire. From The Origin To The Early $19^{\text {th }}$ Century: Sketches On Sociopolitical And Economic History] / Russian History Institute of Russian Academy of Science. Moscow: Russkaia panorama, 2011. 878 p.

25. Rossiia i mir. Novaia epokha. 12 let, kotorye mogut vsyo izmenit' [Russia And The World. The New Era. The Twelve Years That Can Change Everything] / edited by S. Karaganov. Moscow: AST: Rus'-Olimp, 2008. P. 438.

26. Smirnov P.I. O sotsiologicheskom modelirovanii obschestvennoy evoliutsii [On Sociological Modelling of Social Evolution] // Sotsiologicheskie issledovaniia. 2004. № 8. P. 12-22.

27. National Security Strategy of the Russian Federation to 2020 // The Russian Federation Security Council Website: http://www.scrf.gov.ru.

28. Taylor T. Amerikanskiy soldat v sovetskom tanke. Voyna Dzhozefa Bayerli v voyskakh SSHA $i$ SSSR [American Soldier In A Soviet Tank. The War Of Joseph Beyrle In The Troops Of The USA And USSR (The Simple Sounds Of Freedom] / T. Taylor. Moscow, Obschestvo sokhraneniia literaturnogo naslediia, 2010. 320 p.

29. Fedotova V.G. Khoroshee obschestvo [The Good Society]. Moscow: Progress-Traditsiia, 2005. 544 p.

30. Filosofsko-matematicheskiy aspect setevotsentricheskikh deystviy [The Philosophic And Mathematic Aspect Of Web-Centric Activities] // Voennaya mysl', 2013. No.6. P.21.

31. Forester D. Mirovaia dinamika [World Dynamics]. Moscow: OOO AST Publishing House. Saint Petersburg, 2003.

32. Khobsbaum E. Mirovye voyny XX veka: znachenie i posledstviia [The World Wars Of The $20^{\text {th }}$ Century: Significance And Consequences] // Voyna i geopolitika. Vol. 3. Vremia mira. Novosibirsk, 2003. P.225.

33. Chomsky N. Novyy voennyy gumanizm: uroki Kosova [New Military Humanism: Kosova Lessons] Moscow: PRAKSIS Publishing and consulting house, 2012. P.3.

34. Chekinov S.G., Bogdanov S.A. O kharaktere $i$ soderzhanii voyny novogo pokoleniia [On The Character And Content Of The New Generation War] // Voennaia mysl', 2013. № 10. P. 22.

35. Churinov N.M. Ideologiia gosudarstvennogo myshleniia [State Thinking Ideology] // Teoriia $\mathrm{i}$ istoriia. 2007. № 2. P. 11. 
36. Churinov N.M. Vidy sotsial'nogo progressa [Types Of Social Progress] // Kul'tura informatsionnogo obschestva. Krasnoyarsk, 2003. P. 51.

37. Shuper V.A. Rossiia v globalizovannom mire: al'ternativy razvitiia [Russia In The Globalized World: Development Prospectives] // Voprosy filosofii, 2008, № 12. P. 19

38. Iakhnin E.D. Evoliutsiia i buduschee chelovecheskogo sotsiuma (obschenatsional'naia ideia Rossii v mirovom kontekste) [Evolution And Future Of The Human Society (All-Nation Concept Of Russia In The Global Aspect] // Voprosy filosofii, 2006, № 5. P. 174.

39. Iatsenko M.P. Globalizatsiia kak forma organizatsii istoricheskogo protsessa [Globalization As A Form Of Historical Process Organization] // A.I. Herzen Russian State Pedagogical University Newsletter, 2009. № 111. P. 109.

\title{
Военный прогресс в глобальном мире: новые тенденции и проблемы
}

\section{С.В. Максимов}

Сибирский федеральный университет

Россия, 660041, Красноярск, пр. Свободныий, 79

\begin{abstract}
В статье анализируются особенности проявления военного прогресса в глобальном мире. Автор исходит из тезиса, что военный прогресс выступает как часть соииального прогресса. Показано, что военный прогресс носит противоречивый характер, поскольку может проявляться не только как прогресс техники. В статье обращается внимание на тот факт, что военный прогресс можно охарактеризовать при помощи таких понятий, как доблесть, патриотизм, отвага. Автор доказывает, что в разных обществах военный прогресс может протекать в зависимости от исторических традииий.

Военный прогресс представляет собой постоянно меняющуюся систему, которая в одном случае начинает приобретать актуальное значение, принимая одни параметры, а в другом случае - принципиально иные параметры. Именно это дает возможность исследовать различные структуры военного прогресса и изучать динамику того, что выходит на первый план и раскрывается как военный прогресс в данный исторический период. Кроме того, военный прогресс должен представлять наступательную составляющую сочиального прогресса, поскольку именно военный прогресс максимально характеризует адекватность общества в его способности противостоять внешней угрозе.

Понимание сущности военного прогресса предполагает учет характера развертывания его, а также показатели экономической, политической, духовной и соииальной сфер общественной жизни. Военный прогресс должен строиться таким образом, чтобы противник находился все время в догоняющем и непредсказуемом для него режиме. Это очень важно, поскольку удержание противника в таком режиме создает условия, при которых он чувствует свою слабость. В этом случае военный прогресс отвечает чаяниям общество. В частности, военные выставки призваны продемонстрировать те виды вооружений, которые отсутствуют у противника, - тогда он чувствует свою слабость в духовном, социальном, политическом, экономическом аспектах военного прогресса.

По мнению автора, диалектический подход к военному прогрессу предполагает несколько принципиальных направлений. Если военный прогресс выступает как составляющая наступательного прочесса в общественной жизни, то в этом случае нужно продумать стратегию и тактику. Стратегия предполагает ситуаџию, при которой противник всё
\end{abstract}


время находится в напряжении длительный период времени: он вынужден думать о нас, предполагая, что мы предпримем, куда движется наша мысль. Мы должны создавать у противника ситуацию энтропии, и его деяния долюны быть более затратные, максимально неудобные для общества. Для решения подобных задач необходимо постоянно и глубоко изучать противника. Важно серьезно мыслить о том, какими должны быть наши действия, чтобы противник делал необдуманные шаги, которые к тому же являлись бы особо затратнымми.

Военный прогресс тесно связан с потенциальной войной, которая в глобальном мире приобретает новые чертыл. Глобальные связи создаются сетью глобальных коммуникаций, военными и военно-техническими факторами, экологическими проблемами, миграционными процессами, расширяюшимися международными контактами всякого рода, особенно культурными, системоймеждународных отношений, необходимостью регулировать процессы в мировом сообшестве.

Как показывает автор, военный прогресс в современном глобальном мире определяется принциипами антропоцентризма и дуализма, характеризующчими метафизический метод, который предполагает изучение явлений изолированно друг от друга, а источником развития является столкновение внешних противоположных сил.

Сложность, динамичность, аритмичность, запутанность и многоакторность современной войны позволяют говорить о появлении нового типа войн, которые могут быть названы многомерными нелинейными войнами. Важно адекватно понять, по каким направлениям и аспектам современной многомерной нелинейной войны применение кибероружия может дать максимальный результат.

Противопоставляя русский путь развития европейскому, российские философы сходятся с западными в выделении таких черт прогресса, как утрата подлинной человеческой личности, доминирование ичивилизацчионного (машинного, искусственного) начала над культурнылм (духовныл, экзистенцчиальныл). Различие кроется в понимании источника духовной культуры. В европейских представлениях это автономная личность, руководствующаяся индивидуальной системой цуенностей и культурныли нормативами. В российской философии эта личность является отражением божественного начала, раскрытие которого связано с восхождением от индивидуальности всеобщей гармонии.

Ключевые слова: военный прогресс, глобальный мир, региональные конфликты, военное противостояние, соичильный прогресс, военная угроза, кибероружие.

Научная специиальность: 09.00.00 - философские науки. 